\title{
Model Experimental Study of Carbon Fiber Heating Wire for Deicing and Snow Melting on a Bridge Deck
}

\author{
Yan Tan $(\mathbb{D}$, Yuntao Zhu $(\mathbb{D}$, and Henglin Xiao \\ Department of Structural Engineering, School of Civil Architecture and Environment, Hubei University of Technology, \\ Wuhan 430068, China \\ Correspondence should be addressed to Henglin Xiao; xiaohenglin@hbut.edu.cn
}

Received 1 May 2020; Revised 17 June 2020; Accepted 7 July 2020; Published 23 July 2020

Academic Editor: Qiang Tang

Copyright $(92020$ Yan Tan et al. This is an open access article distributed under the Creative Commons Attribution License, which permits unrestricted use, distribution, and reproduction in any medium, provided the original work is properly cited.

In order to use the carbon fiber heating wire more efficiently and safely, the influence of the built-in carbon fiber heating wires (CFHWs) on the temperature changes of the bridge deck is studied in this paper. The model experiments of the temperature rise and ice melting are carried out in a room with low temperature cold storage environment, and the temperature variation of the specimens under different ambient temperatures, namely, $-2,-4$, and $-8^{\circ} \mathrm{C}$, was measured. The results show that, in the temperature rise experiment, the temperature change rate of the measuring points of the surface layer in the central part above $\mathrm{CFHW}$ is the most obvious, with the temperature change rate of $2.123^{\circ} \mathrm{C} / \mathrm{h}$; owing to the limited radiation range of CFHW, the temperature change rate of the measuring points between the CFHW and the CFHW of the surface layer decreases significantly, with a value of $0.703^{\circ} \mathrm{C} / \mathrm{h}$, and the temperature of the measuring points of the heating layer where CFHW is located shows a nearly linear increase, with a temperature change rate of $1.313^{\circ} \mathrm{C} / \mathrm{h}$. The temperature of the bridge deck is basically above $0^{\circ} \mathrm{C}$ as most of the heat generated by CFHW is transferred to the bridge deck after heating, which can effectively prevent the bridge deck from freezing. In the ice melting experiment, the temperature change rate of the measuring points of the surface layer in the central part above the CFHW is $1.406^{\circ} \mathrm{C} / \mathrm{h}$, and the maximum temperature change rate of the measuring points between the CFHW and $\mathrm{CFHW}$ of the surface layer is $0.408^{\circ} \mathrm{C} / \mathrm{h}$. The overall ice melting condition on the specimen surface is appreciable. When the heating power is set to $190 \mathrm{~W} / \mathrm{m}^{2}$, the influence of the ambient temperature on the measuring points of the surface layer is negligible, but the influence of the ice melting rate at different positions from the heating wire is obvious. Therefore, it can be seen that optimizing the layout of the CFHW can effectively improve the whole uniformity and efficiency of ice melting of the bridge deck. The results from relevant research can provide a reference for the design and operation of deicing and snow melting applications on a bridge deck.

\section{Introduction}

The snow easily forms thin ice under the effect of temperature change and vehicle load, which causes traffic accidents, especially in the special areas such as the entrance and exit of highways, bridges, and tunnels [1]. In some areas, there are often severe weather conditions such as freezing rain and sleet in winter. Furthermore, with the large height difference of the bridge and road, the bridge deck is not supported by geothermal energy that makes the pavement easy to freeze. Hence the bridge pavement should be the key part of the deicing.

Currently, the road snow melting and ice deicing mainly include the methods of clearing, self-stressing road snow melting, chemical melting, and thermal melting. There are two types of cleaning methods, namely, manual cleaning and mechanical cleaning. Manual removal method can only be used in light snow or small area [2], whereas mechanical removal method has low removal rate, high equipment prices, high use costs, and later repair costs, besides the possibility of irreparable damage to the pavement $[3,4]$. Zhang [5], Zhang [6], and Luo [7] have studied the selfstressing road snow melting method and inspected the snow and ice melting effect of asphalt concrete with high elastic rubber particles and believed that it has a better effect on the snow and ice melting. The chemical melting method can be categorized with respect to the types of chemical agents employed, i.e., chloride snow melting and organic snow 
melting. The chemical composition of the chloride snow melting agent will alter with snow melting and air [8-10], infiltrate into the soil, pollute the groundwater resources, and destroy the ecological balance [11-13]. Organic snow melting agent has little impact on the environment and little damage to plants and roads, but it is expensive and not suitable for large-scale use. It is generally used in special areas such as airport runways [14-16]. Geothermal energy is used as the main heat source in the early snow melting and ice melting experiment. Ünalf et al. [17] have utilized the geothermal pipe method to melt snow and ice on the road. The liquid in the condensation pipe is heated to vaporize, and the road absorbs the heat from the gas in the pipe and liquefies it to form a cycle, i.e., to melt snow and ice in the way of latent heat transfer. Xie et al. [18] have studied the heat transfer mechanism, the melting rate, and the change of ice temperature of the infrared deicing process and henceforth measured and analyzed the temperature of the melting water and the energy consumption of deicing under different conditions. Tan et al. [19] have established the heat and moisture coupled snow melting model of the road snow melting system that is heated by the solar energy soil source and thermal energy composite fluid, and further the model program was compiled to realize the snow melting system simulation. Daniels [20] has combined the solar energy and heating wire to determine the use of embedded surface heating wire with photovoltaic system to develop anti-ice pavement system. Zhang et al. [21] have studied the heating law of snow and ice melting on the road surface of highway and bridge in terms of the cable heating method. Won et al. $[22,23]$ have studied the cement-based conductive concrete through energizing it to generate heat to achieve the effect of self-heating and then performed snow melting and ice melting on the road surface. Hao et al. [24] have studied the arrangement of the built-in carbon fiber heating wire in the pervious concrete, as a snow and ice melting device, and analyzed its snow melting effect and economic cost. Mohammed [25] has studied the influence of installation depth of carbon fiber heating plate, concrete humidity, and carbon fiber shape on the temperature. The results show that carbon fiber electric heating can provide a feasible solution for ice formation. Zhao et al. [26] proposed a method of deicing with carbon fiber electric heating wires (CFHWs) embedded inside concrete slabs. In order to meet the uniform temperature requirements on the road surface for deicing, the maximum allowable CFHW interval is determined by the finite element method and laboratory experiments. CFHWs were used to heat the concrete slabs and then further verified the effectiveness of the proposed method of deicing with CFHWs in a refrigerator at $-25^{\circ} \mathrm{C}$. Zhang et al. [27] used a finite element method to analyze the deicing performance of the carbon fiber electric heating wire embedded in the concrete pavement. Using ANSYS thermal analysis module, a finite element analysis model of CFHW concrete pavement is established, and the melting time of ice with different thicknesses is summarized.

Deicing and snow melting have been studied to some extent at home and abroad. The methods of geothermal pipe and solar heating are more dependent on the environment and terrain, with a high initial investment cost. Moreover, the infrared heating method is significantly affected by the wind, besides a slow heating rate. The electric energy conversion rate of cable heating is low with a large energy consumption, which can be easily damaged in long-term use. It is difficult to control the content of conductive materials using conductive concrete, which heavily risks the strength and stability of concrete under long-term use. Compared to other ways of deicing and snow melting, the carbon fiber heating wire, as a novel heating material, has good conductivity, high strength, good thermal stability, and higher conversion efficiency of electric energy, and it is relatively easier for laying in actual construction. Researches revealed that the carbon fiber heating wire is better than other deicing methods in the application of snow and ice melting on the bridge deck [28, 29]. However, there is a paucity of investigations over certain fields, for the influence of the built-in carbon fiber heating wire on the ice melting rate and the uniformity of melting ice of the bridge deck. Specifically, under different ambient temperatures, the temperature changes of the bridge deck are difficult to obtain.

Therefore, a bridge model specimen, based on the $16 \mathrm{~m}$ simply supported bridge asphalt concrete, has been made. The whole model experiment is carried out in a large-scale constant temperature laboratory; in the specimen, a carbon fiber heating wire is arranged and the temperature probes are embedded in each structural layer to study the temperature rise and ice melting law of the carbon fiber heating wire in the specimen under different ambient temperatures. The rule of temperature change in the process of bridge pavement snow melting and ice melting is obtained, which provides a reference for the design of the actual bridge road snow and ice melting.

\section{Materials and Methods}

2.1. Model Making. The specimen model is made according to the actual structure of the $16 \mathrm{~m}$ simply supported beam asphalt concrete bridge deck. The upper layer is $100 \mathrm{~mm}$ asphalt pavement (40 mmSMA-13 fine-grained modified asphalt $+50 \mathrm{mmAC}-20$ Chinese asphalt concrete), the lower part is $250 \mathrm{~mm} \mathrm{C40} \mathrm{concrete} \mathrm{bridge} \mathrm{deck,} \mathrm{and} \mathrm{the} \mathrm{size} \mathrm{of} \mathrm{the}$ bridge specimen is $1600 \mathrm{~mm} \times 1000 \mathrm{~mm} \times 380 \mathrm{~mm}$. Subsequent to the formation of the specimen, the plastic polystyrene board, which is $50 \mathrm{~mm}$ higher than the surface, is wrapped around the specimen; in such way an excellent heat insulation performance is achieved, for the maximum reduction of the heat loss and the improvement of the effect of snow melting and ice melting. Concurrently, a hole is made in the water retaining wall around the specimen to discharge the water layer gathered on the surface after each experiment. When the heating device is energized, most of the heat generated is transferred upwards and is absorbed by the ice and snow on the road, thereby ensuring the efficient melting of snow and ice with low energy consumption; the bridge model is shown in Figure 1. There are three temperature measuring layers for the specimen, where the first one is the surface layer, with 21 temperature measuring points Nos. 


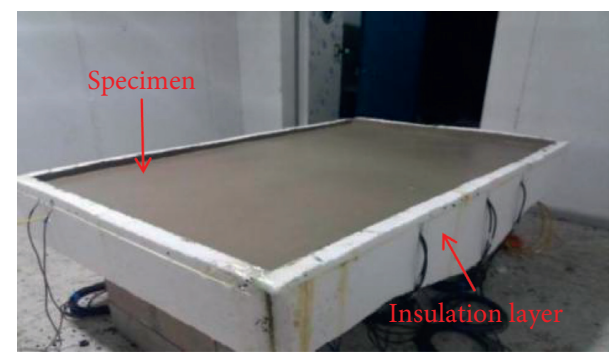

FIgURe 1: Specimen model.

1-21 in total. The second one is the heating layer, with 12 temperature measuring points Nos. 22-32 embedded inside the specimen, and the third one is the bottom layer, with 21 temperature measuring points Nos. 33-54 in total. Both the surface and the bottom layers are applied with external temperature measuring points. The layout of measuring points is shown in Figure 2 (only the measuring points used in this experiment are shown in the figure).

2.2. Experiment Materials and Devices. Carbon fiber is mainly divided into two categories; namely, one is PANbased carbon fiber made from polyacrylonitrile, and the other is asphalt-based carbon fiber (P-CF) made from asphalt. As shown in Figure 3,12 K silica gel sheath carbon fiber heating wire made of PAN-based carbon fiber is used in this experiment. Two $12 \mathrm{~K}$ silica gel sheath carbon fiber heating wires are selected, whereas the heating power per unit length is $30 \mathrm{~W} / \mathrm{m}$, the maximum heating power $195 \mathrm{~W} /$ $\mathrm{m}^{2}$, and the main performance is shown in Table 1 . The spacing between the two carbon fiber heating wires is $30 \mathrm{~cm}$, which is arranged in a $U$-shape with a buried depth of $5 \mathrm{~cm}$. The arrangement of the carbon fiber heating wire is shown in Figure 4.

The experiment device of the ice melting system of the heating cable of the bridge specimen is shown in Figure 5, where the voltage regulator is used to adjust the voltage of the heating cable. The multifunctional data acquisition control module, LTM8662, processes the temperature data from all measuring points and then transmits it to the personal computer through RS485 communication line to output the data. The environment room terminal controls the PC, which in turn controls the temperature and humidity of the climatic chamber.

2.3. Experiment Introduction. In order to satisfy the authenticity of the simulation experiment, the cold storage was cooled before the experiment. According to the data collected from the temperature measurement points arranged around the cold storage during the process of reducing the ambient temperature of the cold storage from $2^{\circ} \mathrm{C}$ to the test set temperature, as shown in Figure 6, after the ambient temperature has fallen to the set temperature, the ambient temperature is stable with no obvious change. This owes to the adoption of the intermittent refrigeration to keep the ambient temperature constant after the refrigeration equipment reaches the set temperature. Therefore, the rationality of the experiment method of snow and ice melting of the simulated asphalt concrete bridge pavement in the cold storage can be proved.

Three groups of measuring points have been selected for the research. Each measuring point is along the longitudinal direction of the specimen, and every three measuring points are aligned on a straight line. The first group includes the measuring points Nos. 4, 5, and 6. They are all on the surface layer and in the corresponding positions directly above the heating wire. The second group contains the measuring points Nos. 7, 8, and 9, which are all on the surface layer and in the corresponding position between the heating wires. The third group contains the measuring points Nos. 25, 26, and 27 , which are in the heating layer and in the position between the heating wires. The experiment monitoring point arrangement is shown in Figure 7.

2.4. Temperature Rise Experiment. The ambient temperature is set to the values of $-2,-4$, and $-8^{\circ} \mathrm{C}$, respectively. Ensure that the surface of the specimen is dry and conduct the temperature rise experiment for the specimen. First operate the refrigerator to cool the cold storage under three different ambient temperatures. First operate the refrigerator to cool the cold storage, respectively, for 3 hours under three different ambient temperatures to the set temperature and keep them unchanged; then heat the carbon fiber heating wire; the heating power is set to $190 \mathrm{~W} / \mathrm{m}^{2}$ for three hours. Record the start time and the temperature values of each temperature measuring point, and select the temperature data of the heating stage to generate a temperature profile. The mechanism that governs the interaction between the temperature rise of the specimen and the ambient temperature and the energization time of the carbon fiber heating wire has been studied. The experiment group is shown in Table 2.

2.5. Ice Melting Experiment. The ambient temperature of the ice melting experiments is set to $-2,-4$, and $-8^{\circ} \mathrm{C}$. For simulating ice melting experiment, a water film with a thickness of $2 \mathrm{~mm}$ has been applied on the surface of the specimen, and the temperature is lowered until the water layer is all frozen. The icing situation is shown in Figure $8(\mathrm{a})$. Thereafter, the carbon fiber heating wire is started, and the heating power is set to $190 \mathrm{~W} / \mathrm{m}^{2}$, followed by the heating of the specimen and the ice melting experiment. The melting ice situation is shown in Figure $8(\mathrm{~b})$. When the heating of the wire reaches the predetermined working time, the ice layer is basically melted. Simultaneously, the heating cable is closed and the ice melting experiment is completed. The start time and the temperature values of the respective temperature measurement points are recorded until the predetermined heating time is reached. Henceforth we study the mechanism of the melting of the specimen and coupled with the ambient temperature and the working time of the carbon fiber heating wire. The experiment group is shown in Table 3. 


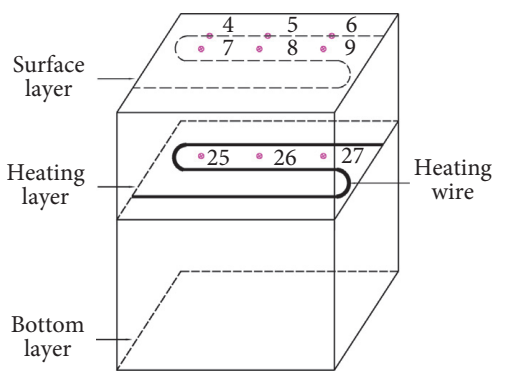

(a)

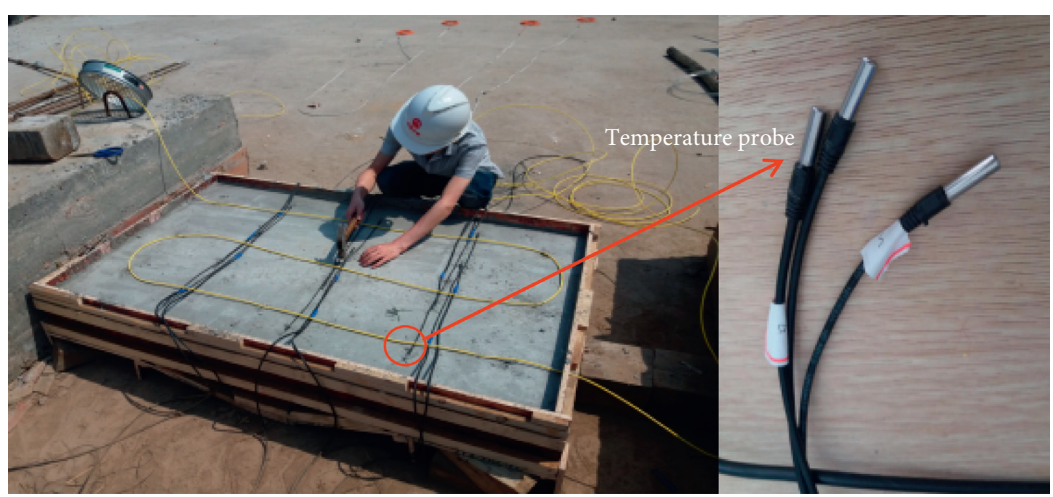

(b)

FIgURE 2: Measuring point layout. (a) The location of the measuring points. (b) Lay the temperature probe.

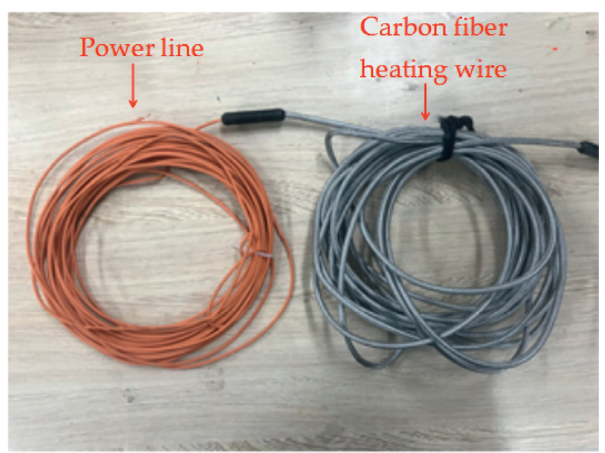

Figure 3: $12 \mathrm{~K}$ carbon fiber heating wire.

TABle 1: Performance of $12 \mathrm{~K}$ carbon fiber heating wire.

\begin{tabular}{lcccccc}
\hline $\begin{array}{l}\text { Mass density } \\
\left(\mathrm{g} / \mathrm{m}^{3}\right)\end{array}$ & $\begin{array}{c}\text { Heatresistance } \\
\left({ }^{\circ} \mathrm{C}\right)\end{array}$ & $\begin{array}{c}\text { Carbon content } \\
(\%)\end{array}$ & $\begin{array}{c}\text { Resistance value } \\
(\Omega / \mathrm{m})\end{array}$ & $\begin{array}{c}\text { Filament diameter } \\
(\mu \mathrm{m})\end{array}$ & $\begin{array}{c}\text { Tensile strength } \\
(\mathrm{MPa})\end{array}$ & $\begin{array}{c}\text { Tensile modulus } \\
(\mathrm{GPa})\end{array}$ \\
\hline $1.76 \sim 1.78$ & 200 & $>93$ & $34 \sim 36$ & $7 \pm 0.2$ & $>3300$ & $>220$ \\
\hline
\end{tabular}

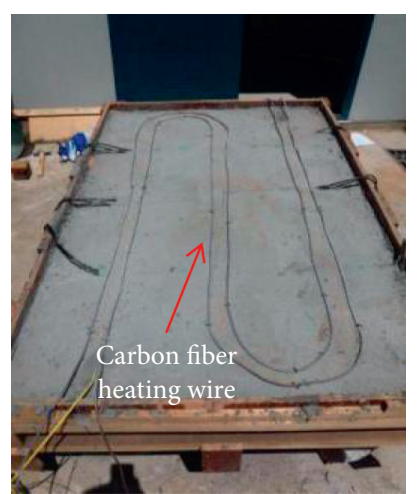

FIgURE 4: Arrangement of the carbon fiber heating wire.

\section{Results}

\subsection{Temperature Rise Experiment Results and Discussion}

3.1.1. Temperature Change Rule of the First Layer Measuring Points (Nos. 4, 5, and 6). The temperature change curves of measuring points Nos. 4, 5, and 6 of the first layer at $-2,-4$, and $-8^{\circ} \mathrm{C}$, respectively, are shown in Figure 9. The corresponding temperature change rates of the aforementioned three measuring points are shown in Table 4. It can be seen from Figure 9 that when the temperature is lowered for 3 hours, the average temperatures of the measuring points are $1.31^{\circ} \mathrm{C}$ and $1.52^{\circ} \mathrm{C}$ under the conditions of $-2^{\circ} \mathrm{C}$ and $-4^{\circ} \mathrm{C}$, respectively. The average temperature values of the measuring points are proximate under the two working conditions. The average temperature of the measuring point at $-8^{\circ} \mathrm{C}$ is $-1.58^{\circ} \mathrm{C}$, and the internal temperature of the specimen is already below $0^{\circ} \mathrm{C}$. After heating for 3 hours, it can be seen from Figure 9(a) that the average temperature of the three measuring points has increased from $1.52^{\circ} \mathrm{C}$ to $7.89^{\circ} \mathrm{C}$ at a temperature of $-2^{\circ} \mathrm{C}$, and the temperature change rate is $2.123^{\circ} \mathrm{C} / \mathrm{h}$. According to Figure 9(b), the average temperature of the three measuring points has increased from $1.31^{\circ} \mathrm{C}$ to $6.96^{\circ} \mathrm{C}$, at $-4^{\circ} \mathrm{C}$, and the temperature change rate is $1.883^{\circ} \mathrm{C} / \mathrm{h}$. It can be seen from Figure 9 (c) that, at $-8^{\circ} \mathrm{C}$, for three measuring points, the average temperature has 


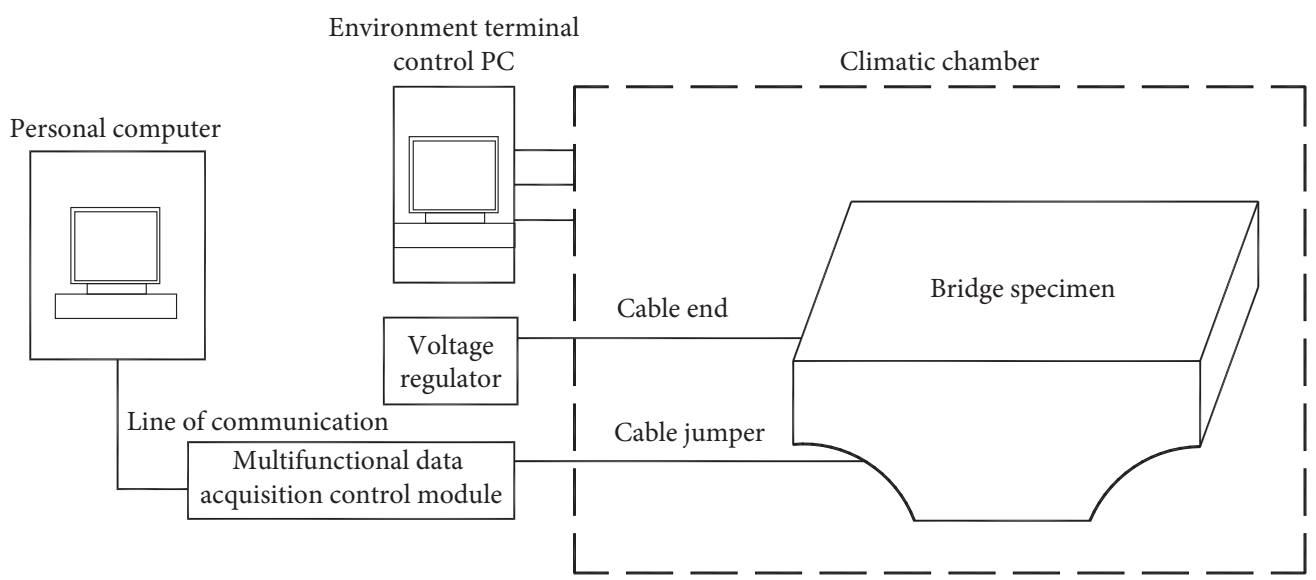

FIgURE 5: Experimental device for heating cable melting system.

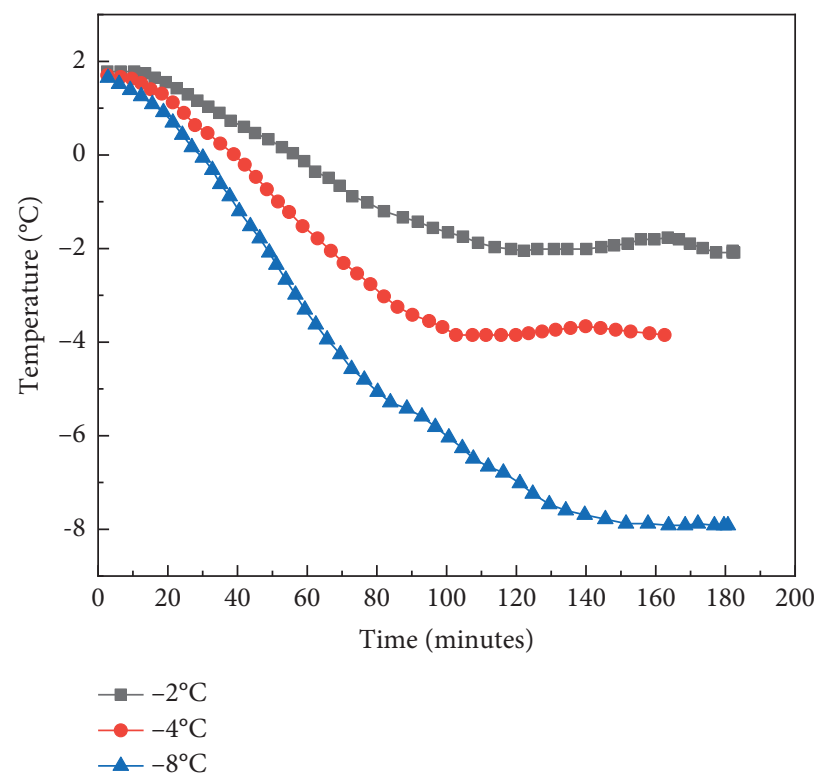

FIgURE 6: Temperature change of cold storage.

increased from $-1.58^{\circ} \mathrm{C}$ to $3.96^{\circ} \mathrm{C}$, and the temperature change rate is $1.846^{\circ} \mathrm{C} / \mathrm{h}$.

It can be seen from Table 4 that the temperature change rates of the three measuring points Nos. 4, 5, and 6 are very close, the temperature change effects are the same, at $-4^{\circ} \mathrm{C}$ and $-8^{\circ} \mathrm{C}$, the temperature change rate is highest, and the temperature change effect is the best, at $-2^{\circ} \mathrm{C}$. It can be seen from the comparison that the change of the ambient temperature has little effect on the ice melting efficiency of the heating wire. Under the three conditions, the temperature change of the No. 4 measuring point is significantly higher than that of the No. 5 and No. 6 measuring points, which is related to the position of the measuring point. It shows that, due to different layouts of heating wire, the temperature change at the corner is the most obvious, and the temperature rise is the fastest.
3.1.2. Temperature Change Rule of the First Layer's Measuring Points (Nos. 7, 8, and 9). The temperature change curves of measuring points Nos. 7, 8, and 9 of the first layer, at $-2,-4$, and $-8^{\circ} \mathrm{C}$, respectively, are shown in Figure 10, and the temperature change rates of the three measuring points are shown in Table 5. It can be seen from Figure 10(a) that the average temperature of the three measuring points has increased from $1.1^{\circ} \mathrm{C}$ to $3.21^{\circ} \mathrm{C}$ at a temperature of $-2^{\circ} \mathrm{C}$, and the temperature change rate is $0.703^{\circ} \mathrm{C} / \mathrm{h}$. According to Figure 10(b), the average temperature of the three measuring points has increased from $0.75^{\circ} \mathrm{C}$ to $2.16^{\circ} \mathrm{C}$ at a temperature of $-4^{\circ} \mathrm{C}$, and the temperature change rate was $0.471^{\circ} \mathrm{C} / \mathrm{h}$. It can be seen from Figure 10(c) that the average temperature of the three measuring points at a temperature of $-8^{\circ} \mathrm{C}$ has increased from $-2.13^{\circ} \mathrm{C}$ to $-0.67^{\circ} \mathrm{C}$, and the temperature change rate is $0.486^{\circ} \mathrm{C} / \mathrm{h}$. The trend of the temperature rise 


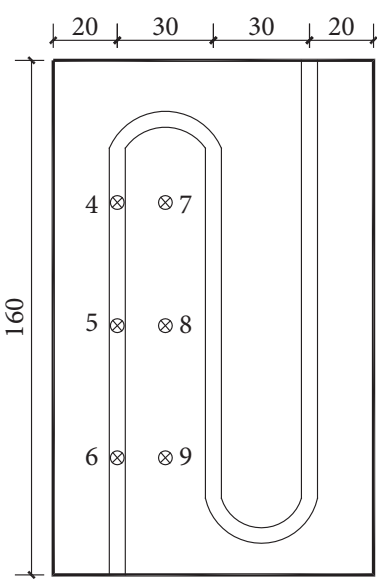

First layer $(\mathrm{cm})$

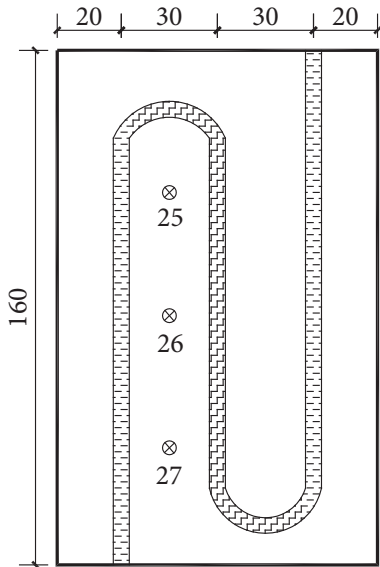

Second layer $(\mathrm{cm})$

Figure 7: Arrangement of temperature measuring points.

TABLE 2: Temperature rise experiment group.

\begin{tabular}{lcc}
\hline Experiment group & Working conditions $\left({ }^{\circ} \mathrm{C}\right)$ & Heating time $(\mathrm{min})$ \\
\hline First layer (surface layer) (Nos. 4, 5, and 6) & $-2,-4,-8$ & 180 \\
First layer (surface layer) (Nos. 7, 8, and 9) & $-2,-4,-8$ & 180 \\
Second layer (heating layer) (Nos. 25, 26, and 27) & $-2,-4,-8$ & 180 \\
\hline
\end{tabular}

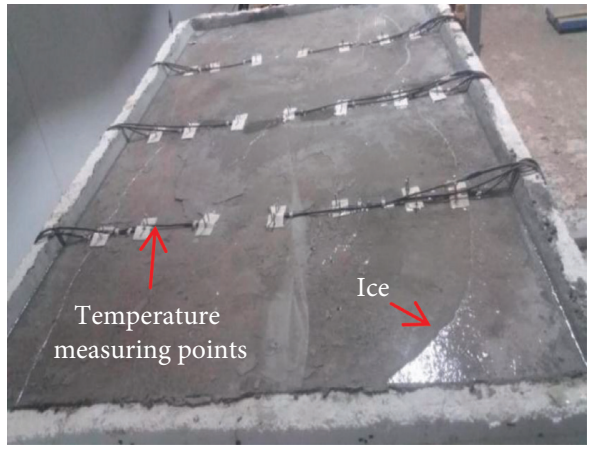

(a)

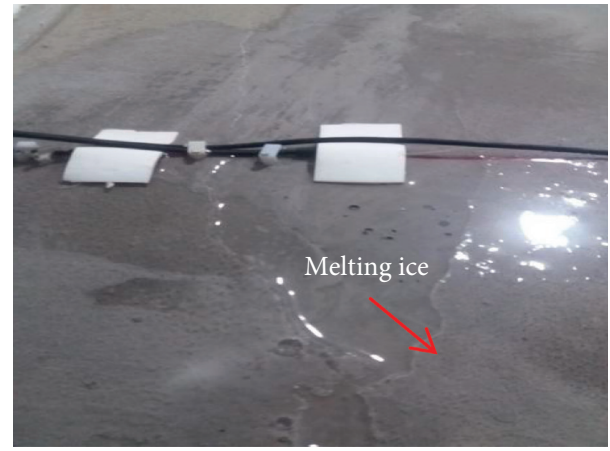

(b)

FIGURE 8: Icing and melting ice under the $-2^{\circ} \mathrm{C}$ working condition: (a) icing and (b) melting ice.

TABLE 3: Ice melting experiment group.

Experiment group

Working condition $\left({ }^{\circ} \mathrm{C}\right)$ Heating time (min)

First layer (surface layer) (Nos. 4, 5, and 6) $-2,-4,-8$ 250

First layer (surface layer) (Nos. 7, 8, and 9) Second layer (heating layer) (Nos. 25, 26, and 27)

$-2,-4,-8$ 250

$-2,-4,-8$ 250

curve of the measuring point can be obtained under three working conditions, the rise of the condition at $-2^{\circ} \mathrm{C}$ is more obvious, the curve corresponding to condition at $-4^{\circ} \mathrm{C}$ is relatively flat, and the rising range is not obvious. The curve corresponding to the condition at $-8^{\circ} \mathrm{C}$ shows that the rise in the first $20 \mathrm{~min}$ is more obvious, and the temperature is basically unchanged after heating for 20-100 min, and then the temperature increases slowly.
It can be seen from Table 5 that, during the 3 hours of heating, the average temperature change corresponding to the measuring points Nos. 7, 8, and 9 in the three working conditions is in the range of $1.4^{\circ} \mathrm{C}$ to $2.2^{\circ} \mathrm{C}$, and the average temperature change of the measuring points Nos. 4,5 , and 6 is in the range of $5.5^{\circ} \mathrm{C}$ to $6.5^{\circ} \mathrm{C}$. Furthermore, most of the heat generated by the heating wire is transferred upward, and the range of heat radiation is limited. Therefore, the 


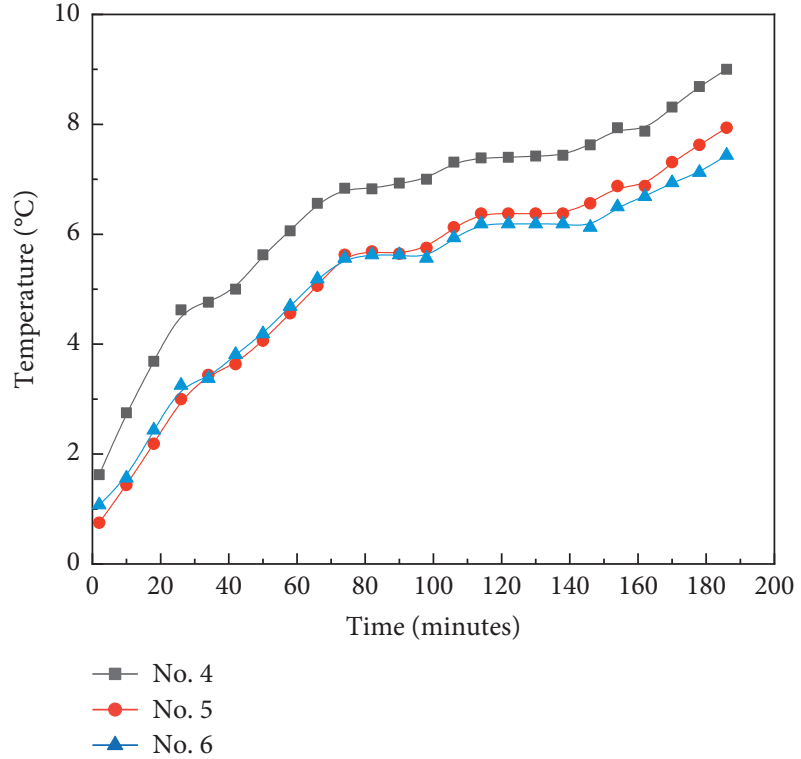

(a)

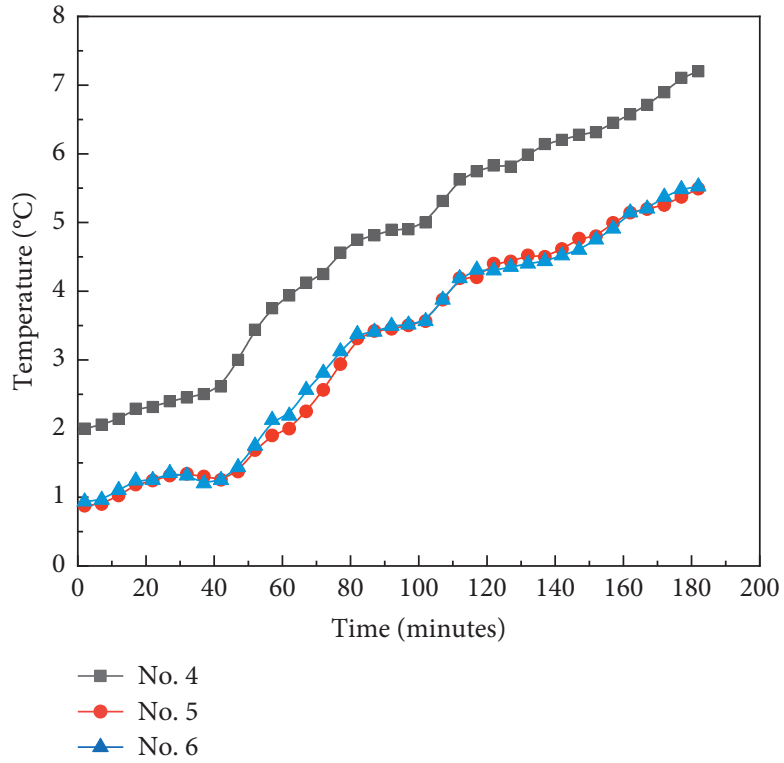

(b)

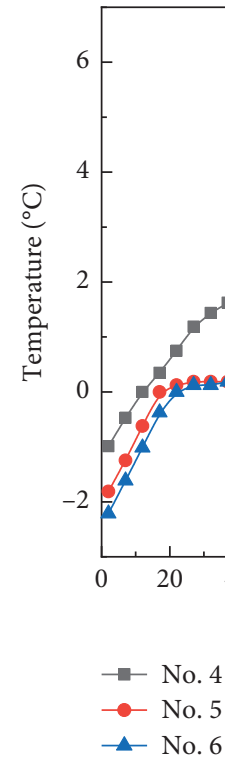

(c)

Figure 9: Temperature change curves of measuring points Nos. 4, 5, and 6 under various working conditions of temperature rise experiment: (a) $-2^{\circ} \mathrm{C}$; (b) $-4^{\circ} \mathrm{C}$; (c) $-8^{\circ} \mathrm{C}$.

TABLE 4: Temperature change rate of the first layer's measuring points Nos. 4, 5, and 6 of the temperature rise experiment.

\begin{tabular}{lccc}
\hline $\begin{array}{l}\text { Environmental conditions } \\
\left({ }^{\circ} \mathrm{C}\right)\end{array}$ & $\begin{array}{c}\text { Average temperature when cooling } \\
\text { for } 3 \mathrm{~h}\left({ }^{\circ} \mathrm{C}\right)\end{array}$ & $\begin{array}{c}\text { Average temperature when heating } \\
\text { for } 3 \mathrm{~h}\left({ }^{\circ} \mathrm{C}\right)\end{array}$ & \begin{tabular}{l} 
Temperature change rate $\left({ }^{\circ} \mathrm{C} / \mathrm{h}\right)$ \\
\hline-2
\end{tabular} \\
-4 & 1.52 & 7.89 & 2.123 \\
-8 & 1.31 & 6.96 & 1.883 \\
\hline
\end{tabular}

temperature change of the measuring point directly above the heating wire is more obvious than the adjacent measuring point.
3.1.3. Temperature Change Rule of the Second Layer's Measuring Points (Nos. 25, 26, and 27). The temperature curves of measuring points Nos. 25, 26, and 27 of the second 


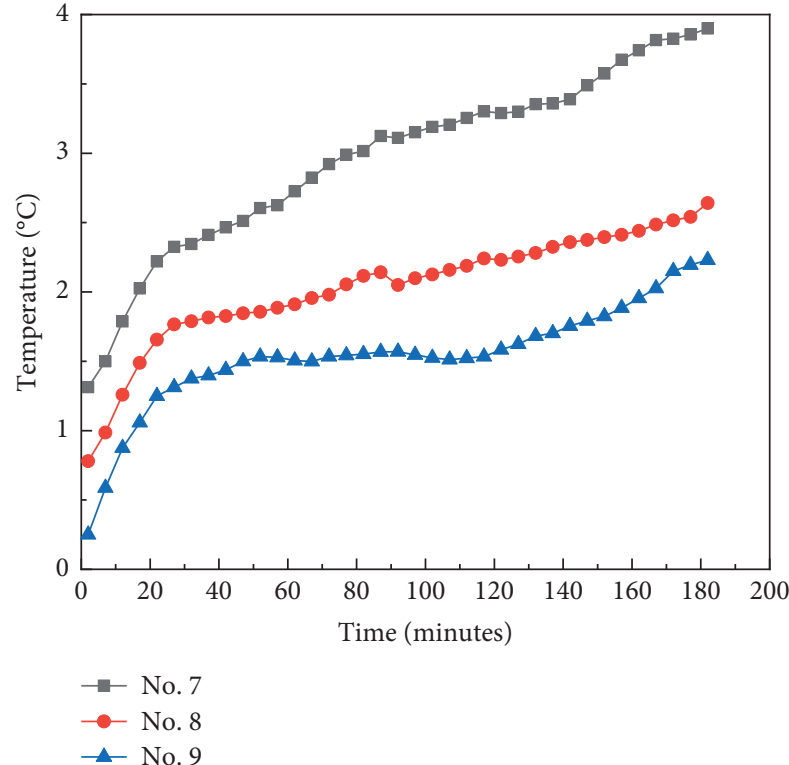

(a)

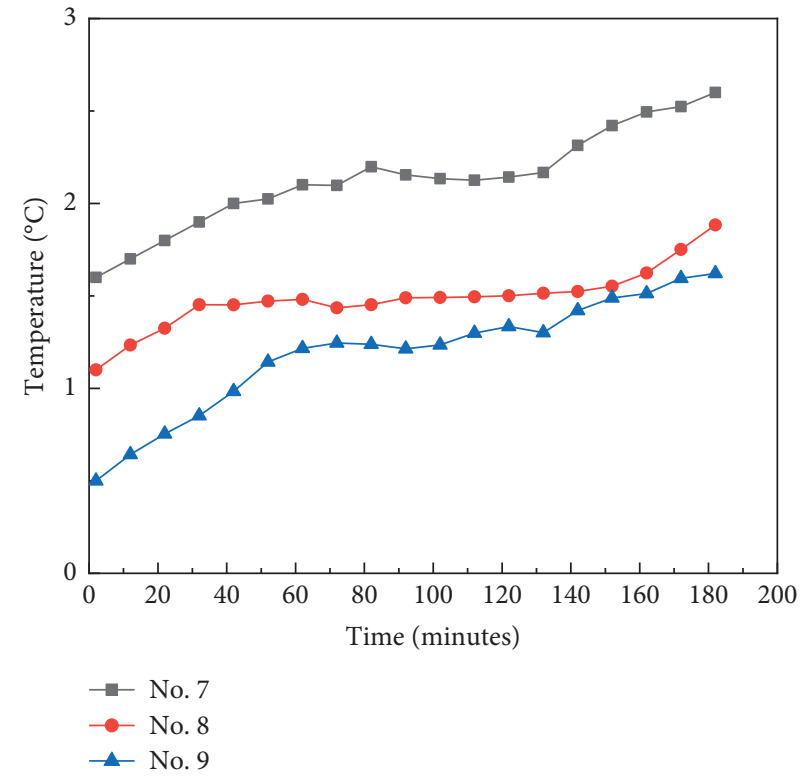

(b)

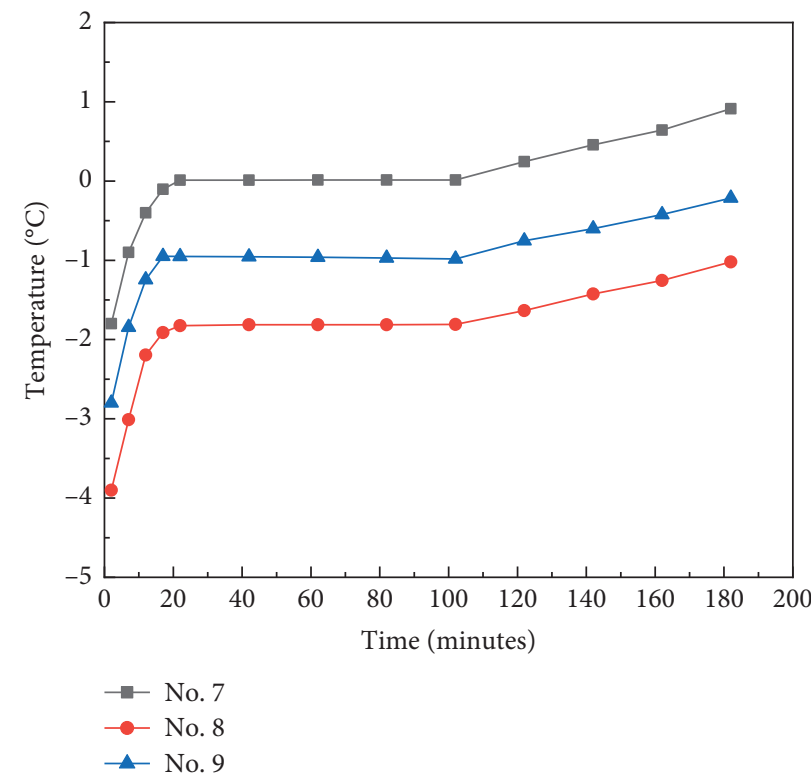

(c)

Figure 10: Temperature change curves of measuring points Nos. 7, 8, and 9 under various working conditions of temperature rise experiment: (a) $-2^{\circ} \mathrm{C}$; (b) $-4^{\circ} \mathrm{C}$; (c) $-8^{\circ} \mathrm{C}$.

TABLE 5: Temperature change rate of the first layer's measuring points Nos. 7, 8, and 9 of the temperature rise experiment.

\begin{tabular}{lccc}
\hline $\begin{array}{l}\text { Environmental conditions } \\
\left({ }^{\circ} \mathrm{C}\right)\end{array}$ & $\begin{array}{c}\text { Average temperature when cooling } \\
\text { for } 3 \mathrm{~h}\left({ }^{\circ} \mathrm{C}\right)\end{array}$ & $\begin{array}{c}\text { Average temperature when heating } \\
\text { for } 3 \mathrm{~h}\left({ }^{\circ} \mathrm{C}\right)\end{array}$ & \begin{tabular}{c} 
Temperature change rate $\left({ }^{\circ} \mathrm{C} / \mathrm{h}\right)$ \\
\hline-2
\end{tabular} \\
-4 & 1.10 & 3.21 & 0.703 \\
-8 & 0.75 & 2.16 & 0.471 \\
& -2.13 & -0.67 & 0.486 \\
\hline
\end{tabular}

layer, at $-2,-4$, and $-8^{\circ} \mathrm{C}$, respectively, are shown in Figure 11 , and the temperature change rates of the three measuring points are shown in Table 6. It can be seen from Figure 11(a) that the average temperature of the three measuring points has increased from $5.5^{\circ} \mathrm{C}$ to $9.44^{\circ} \mathrm{C}$ at $-2^{\circ} \mathrm{C}$, and the temperature change rate is $1.313^{\circ} \mathrm{C} / \mathrm{h}$. According to Figure 11(b), the average temperature of the three measuring points has increased from $5.0^{\circ} \mathrm{C}$ to $8.58^{\circ} \mathrm{C}$, and the 


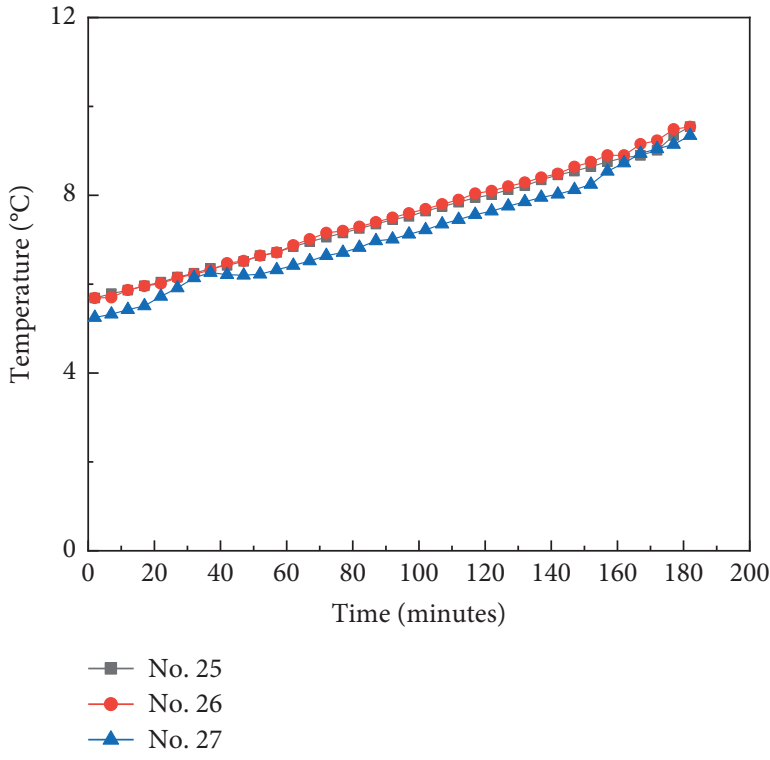

(a)

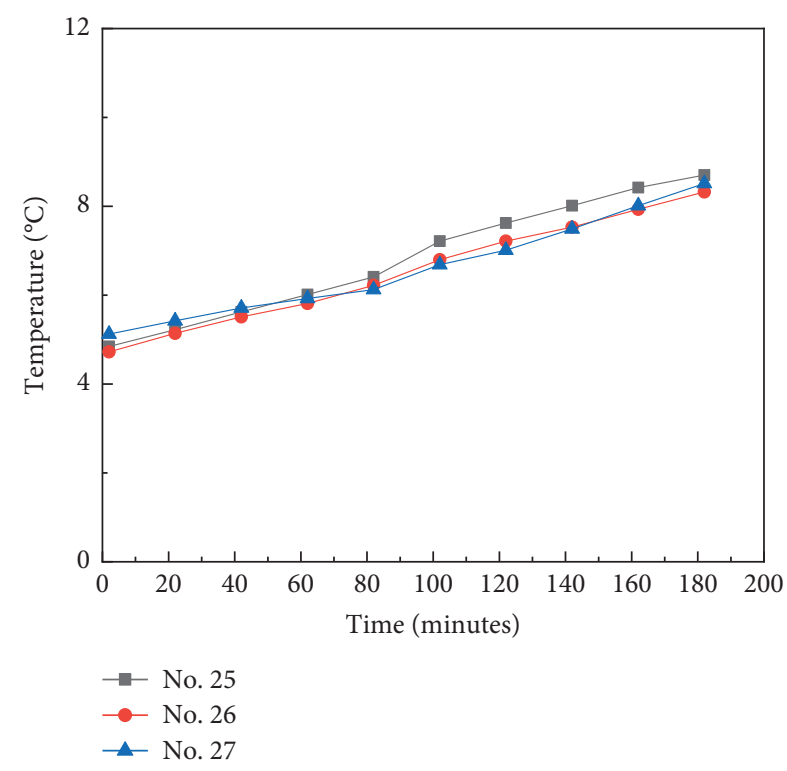

(b)

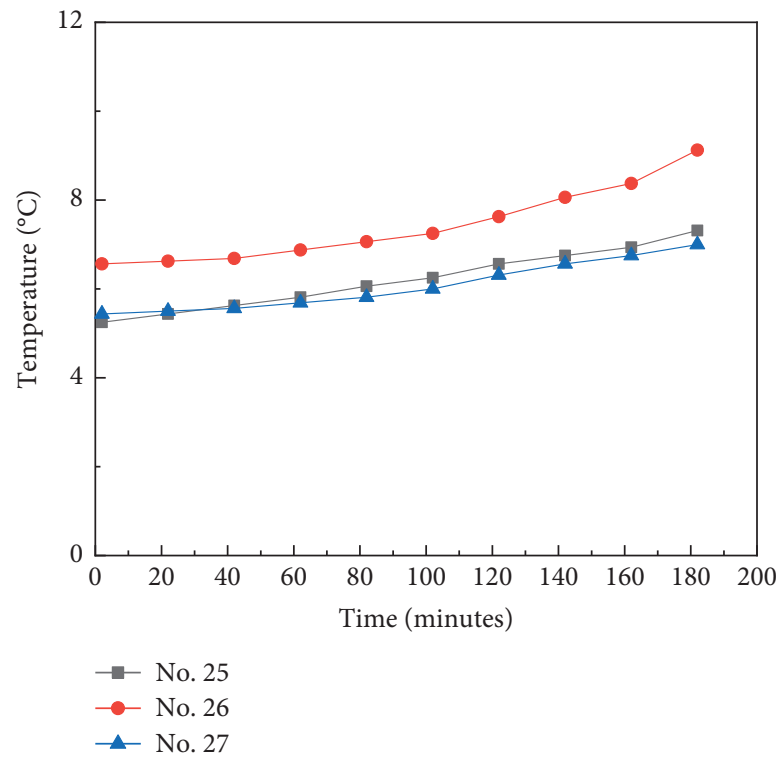

(c)

Figure 11: Temperature change curves of measuring points Nos. 25, 26, and 27 under various working conditions of temperature rise experiment: (a) $-2^{\circ} \mathrm{C}$; (b) $-4^{\circ} \mathrm{C}$; (c) $-8^{\circ} \mathrm{C}$.

TABLE 6: Temperature change rate of the second layer's measuring points Nos. 25, 26, and 27 of the temperature rise experiment.

\begin{tabular}{lccc}
\hline $\begin{array}{l}\text { Environmental conditions } \\
\left({ }^{\circ} \mathrm{C}\right)\end{array}$ & $\begin{array}{c}\text { Average temperature when cooling } \\
\text { for } 3 \mathrm{~h}\left({ }^{\circ} \mathrm{C}\right)\end{array}$ & $\begin{array}{c}\text { Average temperature when heating } \\
\text { for } 3 \mathrm{~h}\left({ }^{\circ} \mathrm{C}\right)\end{array}$ & $\begin{array}{c}\text { Temperature change rate }\left({ }^{\circ} \mathrm{C} / \mathrm{h}\right) \\
-2\end{array}$ \\
\hline-2 & 5.5 & 9.44 & 1.313 \\
-4 & 5.0 & 8.58 & 1.193 \\
-8 & 5.96 & 8.92 & 0.987 \\
\hline
\end{tabular}

temperature change rate is $1.193^{\circ} \mathrm{C} / \mathrm{h}$ in the working condition at $-4^{\circ} \mathrm{C}$. It can be seen from Figure $11(\mathrm{c})$ that the average temperature of the three measuring points increases from $5.96^{\circ} \mathrm{C}$ to $8.92^{\circ} \mathrm{C}$ in the working condition of $-8^{\circ} \mathrm{C}$, and the temperature change rate is $0.987^{\circ} \mathrm{C} / \mathrm{h}$. The temperature rise curves under all the three conditions have shown a nearly linear increase, but the growth rate is not significant.

It can be seen from Table 6 that the average temperatures of measuring points Nos. 25, 26, and 27, before and after heating for 3 hours, are very close. Furthermore, the 
temperature change rate is also the same, whereas the difference with the ambient temperature is large, indicating that the measuring point in the heat generating layer located inside the concrete specimen is less affected by the ambient temperature during the experiment, and the residual temperature of the concrete itself has a certain heat preservation effect. The temperature change rate is lower than the measuring points Nos. 4, 5 and 6, further indicating that the heat is transferred upward inside the specimen.

\subsection{Results and Discussion of Ice Melting Experiment under Four-Side Insulation}

3.2.1. Temperature Change Rule of the First Layer's Measuring Points (Nos. 4, 5, and 6). The temperature profiles of measuring points Nos. 4,5 , and 6 of the first layer, at $-2,-4$, and $-8^{\circ} \mathrm{C}$, respectively, are shown in Figure 12 , and the corresponding temperature change rates of the three measuring points are shown in Table 7. It can be seen from Figure 12(a) that the average temperature of the measuring points Nos. 4,5 , and 6 at $-2^{\circ} \mathrm{C}$ is $-0.46^{\circ} \mathrm{C}$ before the heating. After the heating, the average temperature of the measuring points is found to be $5.4^{\circ} \mathrm{C}$, and the temperature rise rate is $1.406^{\circ} \mathrm{C} / \mathrm{h}$. It can be seen from Figure $12(\mathrm{~b})$ that the average temperature of the measuring points at $-4^{\circ} \mathrm{C}$ is $-0.81^{\circ} \mathrm{C}$ before the heating. After the heating, the average temperature of the measuring point is $4.77^{\circ} \mathrm{C}$, and the temperature rising rate is $1.339^{\circ} \mathrm{C} / \mathrm{h}$. According to Figure $12(\mathrm{c})$, the average temperature of the measuring point at $-8^{\circ} \mathrm{C}$ is $-1.12^{\circ} \mathrm{C}$ before the heating. After the heating, the average temperature of the measuring points is $4.317^{\circ} \mathrm{C}$, and the temperature rise rate is $1.305^{\circ} \mathrm{C} / \mathrm{h}$. It can be seen from Table 7 that the temperature change rates, respectively, are in proximity corresponding to the three temperature conditions, indicating that a certain range of ambient temperature has little effect on the melting ice efficiency directly above the heating wire. The surface layer directly above the heating wire is thoroughly melted under the conditions of $-2,-4$, and $-8^{\circ} \mathrm{C}$.

It can be seen from Figure 12 that the temperature rise curves of the three working conditions are similar, and the temperature of the measuring point basically rises linearly. After the heating, the temperature of the measuring points slowly rises to about $0^{\circ} \mathrm{C}$ and then forms a plateau period. The plateau periods corresponding to different working conditions are different. During this period, the temperature change of the measuring point is not obvious, and the temperature fluctuates slightly around $0^{\circ} \mathrm{C}$. It can be seen from the experimental observation that the ice layer over the surface layer is of a mixed state of ice water. The ice layer on the surface of the specimen has begun to melt in the direction of thickness, especially the portion directly above the heating wire. Since the climatic chamber has been kept in a low temperature environment, the ice layer that just melted to water has been partially refrozen, and hence the temperature curve at this stage fluctuates around $0^{\circ} \mathrm{C}$. After the heating for a period of time, the heat generated by the carbon fiber heating wire is more uniformly transferred to the surface of the specimen, the ice layer on the surface of the specimen melts over a large area, and the temperature of measuring points of the surface layer begins to rise sharply till the end of the heating process.

\subsubsection{Temperature Change Rule of the First Layer's Mea-} suring Points (Nos. 7, 8, and 9). The temperature curves of measuring points Nos. 7, 8 , and 9 of the first layer, at $-2,-4$, and $-8^{\circ} \mathrm{C}$, respectively, are shown in Figure 13. Moreover, the temperature change rates of the aforementioned three measuring points are shown in Table 8. According to Figure 13(a), before the heating, the average temperature of the measuring points Nos. 7,8 , and 9 at $-2^{\circ} \mathrm{C}$ is $-0.78^{\circ} \mathrm{C}$. After the heating, the average temperature of the measuring points is $0.41^{\circ} \mathrm{C}$, and the temperature rise rate is $0.286^{\circ} \mathrm{C} / \mathrm{h}$. According to Figure 13(b), before the heating, the average temperature of the measuring points at $-4^{\circ} \mathrm{C}$ is $-1.23^{\circ} \mathrm{C}$. After the heating, the average temperature of the measuring points is $0.36^{\circ} \mathrm{C}$, and the temperature rise rate is $0.382^{\circ} \mathrm{C} / \mathrm{h}$. According to Figure 13(c), before the heating, the average temperature of the measuring points at $-8^{\circ} \mathrm{C}$ is $-1.37^{\circ} \mathrm{C}$. After the heating, the average temperature of the measuring points is $0.33^{\circ} \mathrm{C}$, and the increment rate of temperature is $0.408^{\circ} \mathrm{C} / \mathrm{h}$. Compared with the measuring points Nos. 4,5 , and 6, the measuring points Nos. 7, 8, and 9 take a longer time of heating to reach the temperatures near $0^{\circ} \mathrm{C}$. After an increase up to $0^{\circ} \mathrm{C}$, the temperature of each measuring point has been maintained at around $0^{\circ} \mathrm{C}$ in the second half of the heating process, with almost no significant increase.

According to Table 8, the measuring points Nos. 7, 8, and 9 are directly above the position between the heating wires, which is $15 \mathrm{~cm}$ away from the heating wires on the left and right sides. Nevertheless the radiation range of the heating wire is limited; hence it is difficult for the radiation to affect the positions beyond $15 \mathrm{~cm}$. This results in the average temperature of the measuring points being maintained in the range of $0.3^{\circ} \mathrm{C}-0.4^{\circ} \mathrm{C}$ in the second half of heating despite sufficient heating time, with practically no upward trend.

3.2.3. Temperature Change Rule of the Second Layer's Measuring Points (Nos. 25, 26, and 27). The temperature curves of measuring points Nos. 25, 26, and 27 of the second layer, at $-2,-4$, and $-8^{\circ} \mathrm{C}$, respectively, are shown in Figure 14 . The temperature change rates of the three points are shown in Table 9. It can be seen from Figure 14(a) that, before the heating, the average temperature of the measuring points Nos. 25,26 , and 27 at $-2^{\circ} \mathrm{C}$ is $-0.12^{\circ} \mathrm{C}$, and, after the heating, the average temperature of the measuring points is $4.83^{\circ} \mathrm{C}$, with the rate of temperature rise at $1.189^{\circ} \mathrm{C} / \mathrm{h}$. According to Figure 14(b), the average temperature of the measuring points at $-4^{\circ} \mathrm{C}$ is $-0.63^{\circ} \mathrm{C}$ before the start of heating. After the heating, the average temperature of the measuring points is $3.08^{\circ} \mathrm{C}$, and the temperature rise rate is $0.891^{\circ} \mathrm{C} / \mathrm{h}$. According to Figure $14(\mathrm{c})$, the average temperature of the measuring points under the conditions of $-8^{\circ} \mathrm{C}$ before the heating is $-0.67^{\circ} \mathrm{C}$. After the heating, the average temperature of the measuring points is $1.58^{\circ} \mathrm{C}$, and the temperature rise rate is $0.541^{\circ} \mathrm{C} / \mathrm{h}$. According to Figure 14, the temperature rise curves of measuring points Nos. 25, 26, 


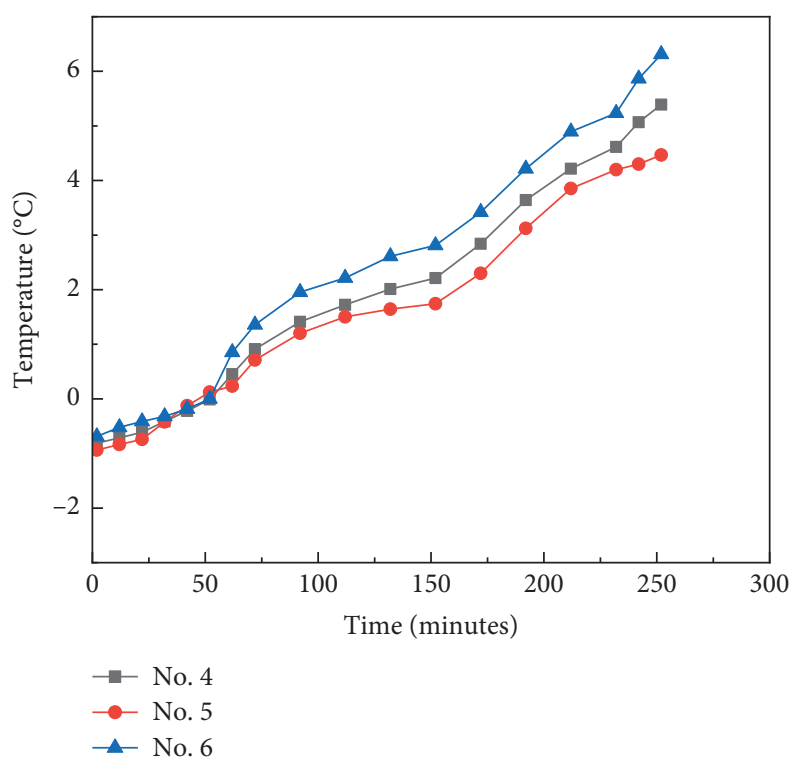

(a)

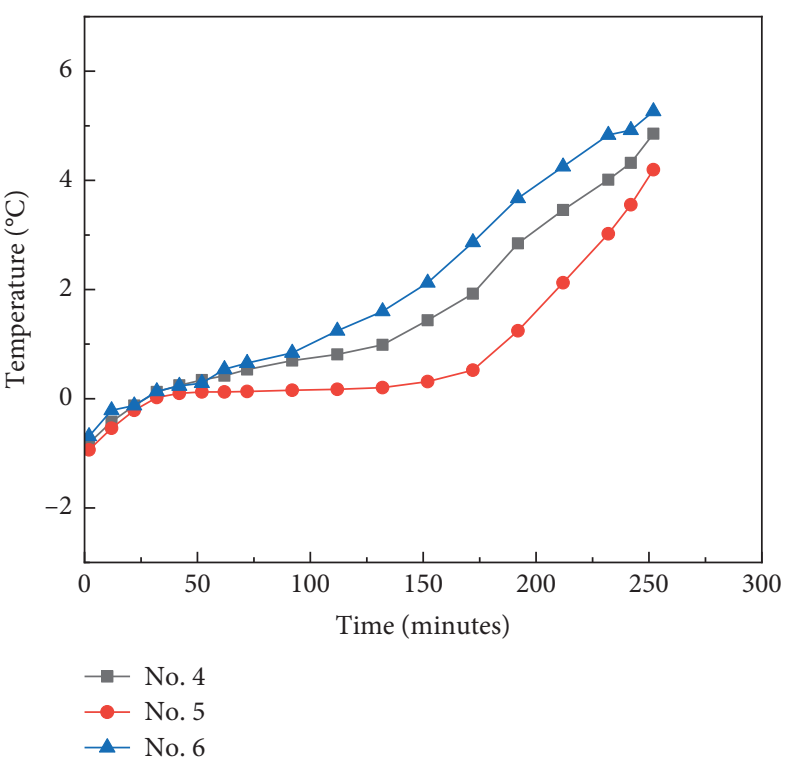

(b)

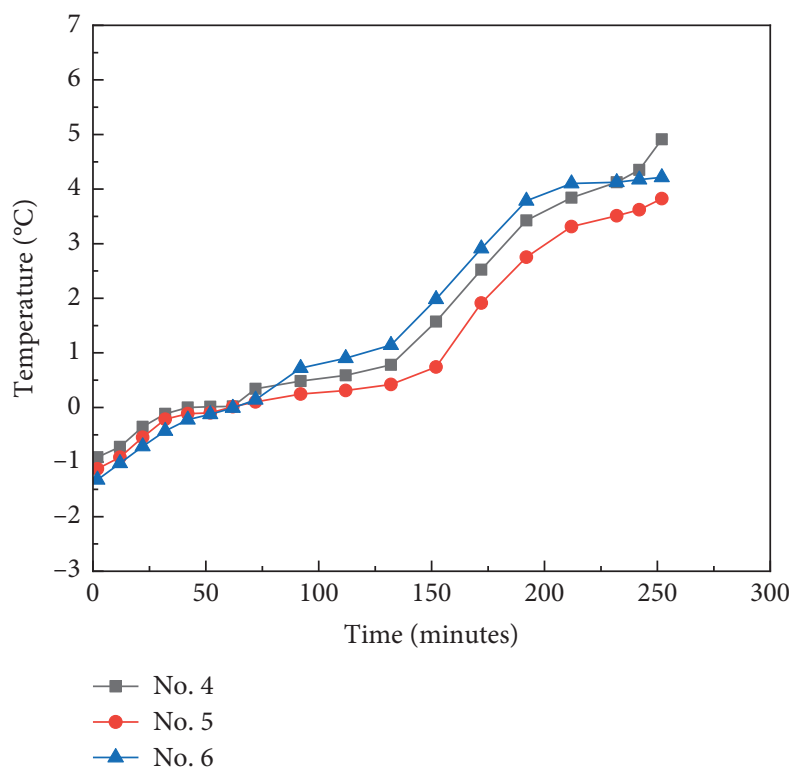

(c)

FIGURE 12: Temperature change curves of measuring points Nos. 4, 5, and 6 under various working conditions of ice melting experiment: (a) $-2^{\circ} \mathrm{C}$; (b) $-4^{\circ} \mathrm{C}$; (c) $-8^{\circ} \mathrm{C}$.

TAвLE 7: Temperature change rate of the first layer's measurement points Nos. 4, 5, and 6 of the ice melting experiment.

Environmental conditions $\left({ }^{\circ} \mathrm{C}\right)$ Initial average temperature $\left({ }^{\circ} \mathrm{C}\right)$ Average temperature at $250 \mathrm{~min}\left({ }^{\circ} \mathrm{C}\right)$ Temperature change rate $\left({ }^{\circ} \mathrm{C} / \mathrm{h}\right)$

\begin{tabular}{lccc}
\hline-2 & -0.46 & 5.4 & 1.406 \\
-4 & -0.81 & 4.77 & 1.339 \\
-8 & -1.12 & 4.317 & 1.305 \\
\hline
\end{tabular}

and 27 of the heating layers are more consistent under different temperature conditions, and it can be approximated as a linear increase. Specifically, the temperature of the measuring points and the heating time are approximately proportional during the heating process.
It can be seen from Table 9 that the temperature rise of the measuring points decreases with the decrease of the ambient temperature. When the temperature of working condition becomes lower, the slope of the corresponding temperature curve becomes smaller. When the temperature 

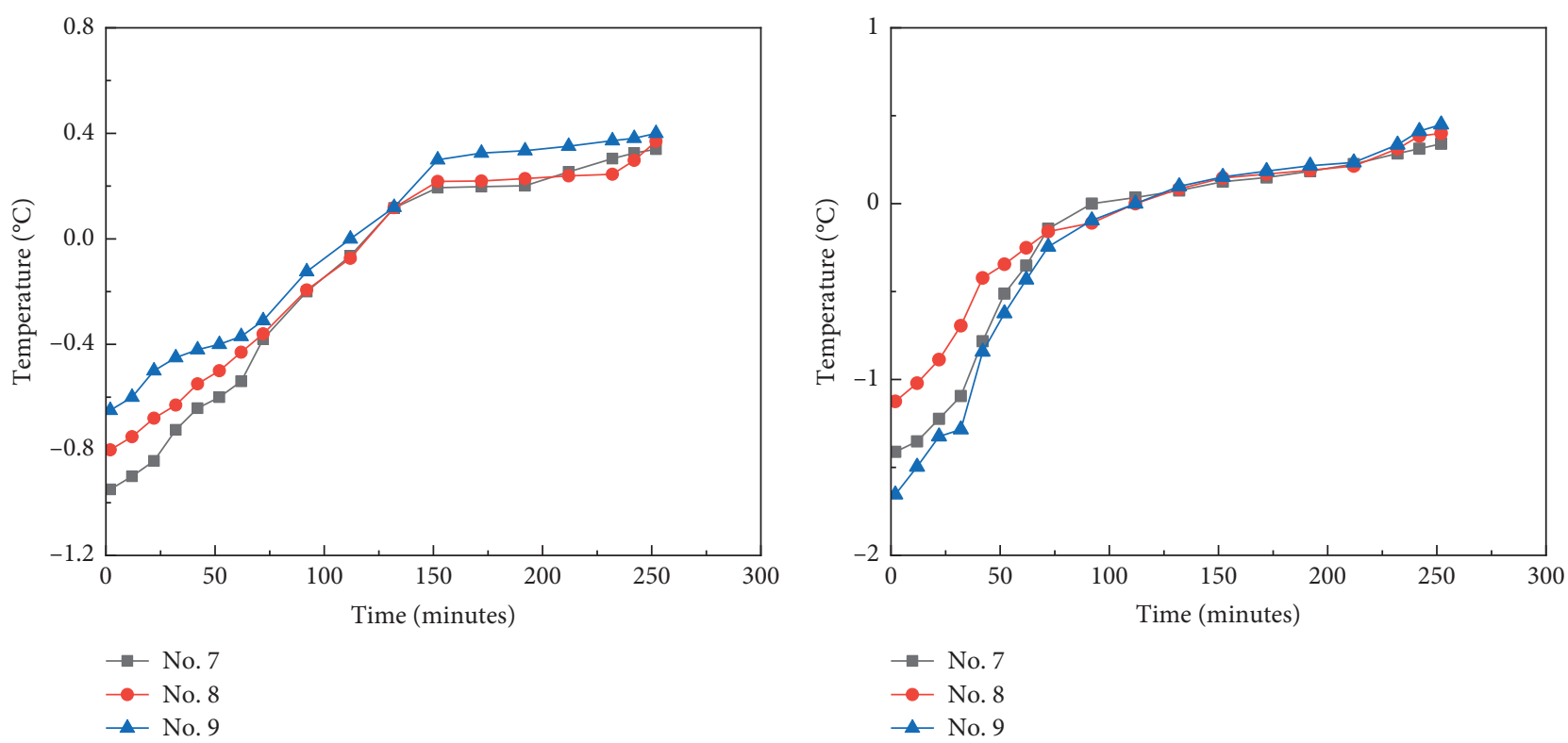

(a)

(b)

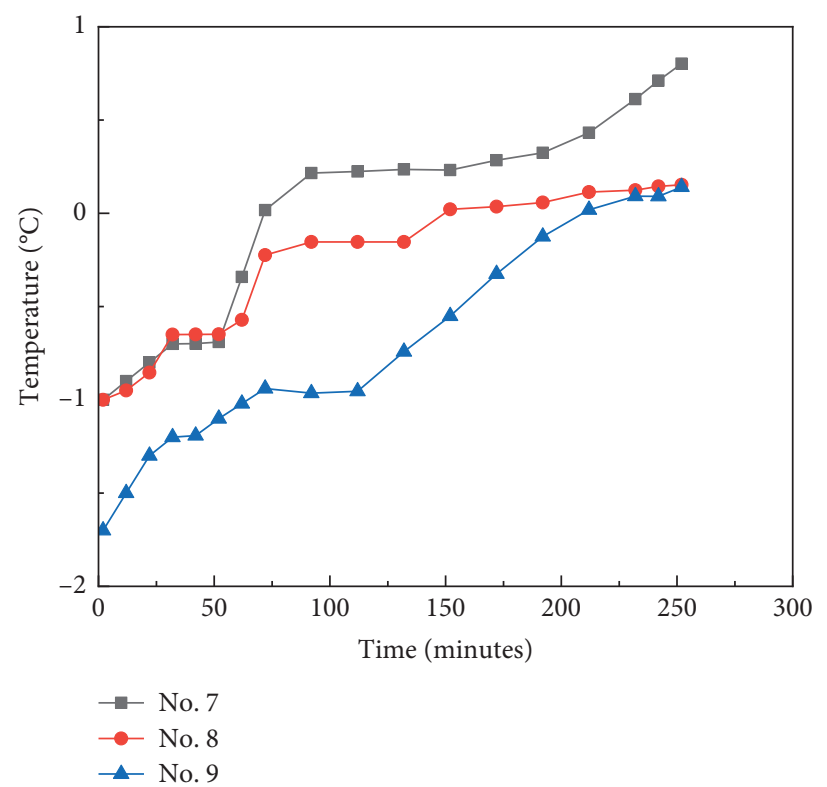

(c)

FIGURE 13: Temperature change curves of measuring points Nos. 7, 8, and 9 under various working conditions of ice melting experiment: (a) $-2^{\circ} \mathrm{C}$; (b) $-4^{\circ} \mathrm{C}$; (c) $-8^{\circ} \mathrm{C}$.

TABLE 8: Temperature change rate of the first layer's measurement points Nos. 7, 8, and 9 of the ice melting experiment.

\begin{tabular}{lccc}
\hline $\begin{array}{l}\text { Environmental conditions } \\
\left({ }^{\circ} \mathrm{C}\right)\end{array}$ & $\begin{array}{c}\text { Initial average temperature } \\
\left({ }^{\circ} \mathrm{C}\right)\end{array}$ & $\begin{array}{c}\text { Average temperature when rising for } 250 \text { min } \\
\left({ }^{\circ} \mathrm{C}\right)\end{array}$ & $\begin{array}{c}\text { Temperature change rate } \\
\left({ }^{\circ} \mathrm{C} / \mathrm{h}\right)\end{array}$ \\
\hline-2 & -0.78 & 0.41 & 0.286 \\
-4 & -1.23 & 0.36 & 0.382 \\
-8 & -1.37 & 0.33 & 0.408
\end{tabular}

of the internal heating layer of the specimen is lower than $0^{\circ} \mathrm{C}$, it is obviously affected by the ambient temperature. As the ambient temperature decreases, the temperature change rate of the measuring point decreases significantly.
Simultaneously, the preheating of the bridge surface can be utilized to keep the internal temperature of the concrete above $0^{\circ} \mathrm{C}$, and the heat generated by the heating wire is more used to melt snow and ice on the surface layer. 

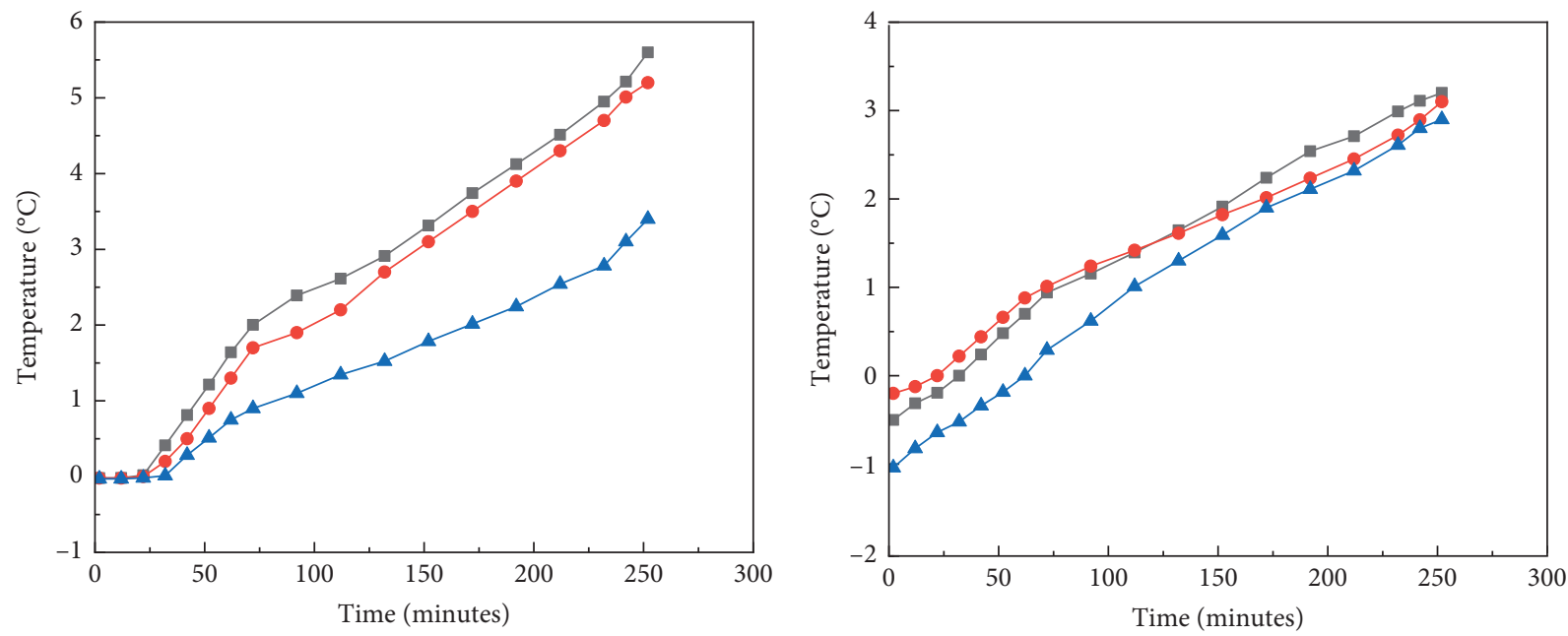

$\rightarrow$ No. 25

$\longrightarrow$ No. 26

$\rightarrow$ No. 25

$\longrightarrow$ No. 26

- No. 27

- No. 27

(a)

(b)

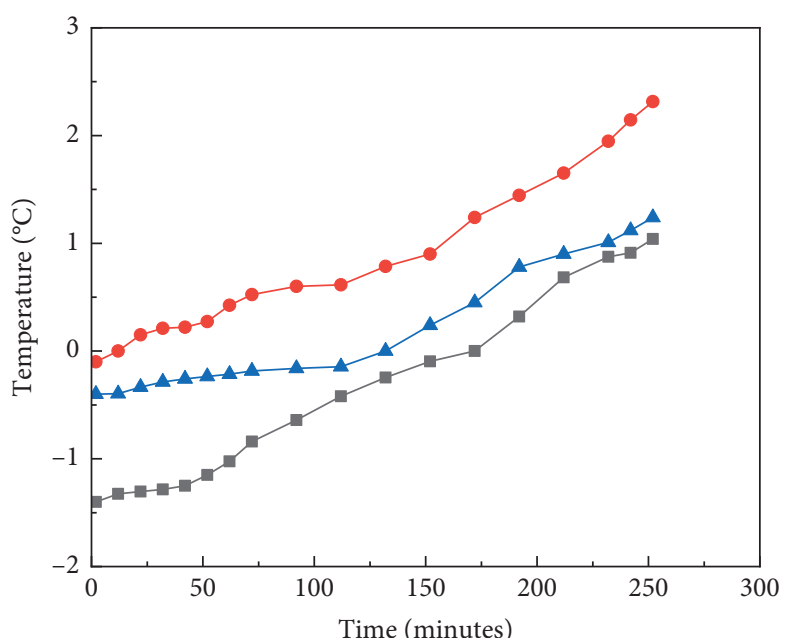

$\rightarrow$ No. 25

$\longrightarrow$ No. 26

$\simeq$ No. 27

(c)

FIGURE 14: Temperature change curves of measuring points Nos. 25, 26, and 27 under various working conditions of ice melting experiment: (a) $-2^{\circ} \mathrm{C}$; (b) $-4^{\circ} \mathrm{C}$; (c) $-8^{\circ} \mathrm{C}$.

TABLE 9: Temperature change rate of the first layer's measurement points Nos. 25, 26, and 27 of the ice melting experiment.

\begin{tabular}{lccc}
\hline $\begin{array}{l}\text { Environmental conditions } \\
\left({ }^{\circ} \mathrm{C}\right)\end{array}$ & $\begin{array}{c}\text { Initial average temperature } \\
\left({ }^{\circ} \mathrm{C}\right)\end{array}$ & $\begin{array}{c}\text { Average temperature when rising for } 250 \text { min } \\
\left({ }^{\circ} \mathrm{C}\right)\end{array}$ & $\begin{array}{c}\text { Temperature change rate } \\
\left({ }^{\circ} \mathrm{C} / \mathrm{h}\right)\end{array}$ \\
\hline-2 & -0.12 & 4.83 & 1.189 \\
-4 & -0.63 & 3.08 & 0.891 \\
-8 & -0.67 & 1.58 & 0.541 \\
\hline
\end{tabular}




\section{Conclusions}

The temperature variation of the specimen under different ambient temperatures has been studied based on the temperature rise experiment and the ice melting experiment on the built-in carbon fiber heating wire bridge. The conclusions are given as follows:

(1) According to the data transferred back from the temperature measurement points arranged around the cold storage, the ambient temperature change in the cold storage during the heating process is within the allowable error range, under the set working conditions, and all changes fluctuate around the set experimental temperature. This proves the rationality of the experiment method for snow melting and ice-making of simulated asphalt concrete bridge deck in cold storage.

(2) In the temperature rise experiment, the temperature change rate, with a value of $2.123^{\circ} \mathrm{C} / \mathrm{h}$, of the measuring points on the surface layer directly above the heating wire is the most obvious. Owing to the limited radiation range of the heating wire, the temperature change rate, with a value of $0.703^{\circ} \mathrm{C} / \mathrm{h}$, of the measuring points between the heating wire on the surface layer and the heating wire decreases significantly. The temperature of the measuring points on the heating layer at the location of the heating wire increases almost linearly, with a temperature change rate of $1.313^{\circ} \mathrm{C} / \mathrm{h}$. Bulk of the heat generated by the heating wire is transferred to the bridge deck. After the heating, the temperature of the bridge deck is nearly above $0^{\circ} \mathrm{C}$, which can effectively prevent the bridge deck from freezing.

(3) When the heating power is set to $190 \mathrm{~W} / \mathrm{m}^{2}$, the surface layer measuring points are less affected by the ambient temperature, and the melting ice rate at different positions from the heating wire is obviously affected. Optimizing the arrangement of the heating wire can effectively improve the overall uniformity of the ice melting of the bridge deck and melting efficiency. To shorten the time of snow melting, it is considered that the bridge is preheated when the outdoor temperature is low, which can effectively control the temperature of bridge surface above $0^{\circ} \mathrm{C}$ to prevent road surface from freezing, and it can also reduce the input power to save energy.

(4) Concrete itself has a good thermal insulation effect. In practical applications, the residual temperature stored in the concrete pavement can be utilized to melt snow and ice. When the temperature of road surface exceeds $0^{\circ} \mathrm{C}$, intermittent power supply is utilized to save energy.

(5) The research on the ice melting experiment of the bridge deck specimen shows that when the ambient temperature values are $-2,-4$, and $-8^{\circ} \mathrm{C}$, the buried depth of the carbon fiber heating wire on the bridge deck is $5 \mathrm{~cm}$, the arrangement spacing is $30 \mathrm{~cm}$, and the surface temperature of the bridge specimen can be evenly distributed, and when the input power of the heating wire is set to $190 \mathrm{~W} / \mathrm{m}^{2}$, the temperature of the bridge deck can be raised to above $0^{\circ} \mathrm{C}$ to meet the requirements of the snow and ice melting.

\section{Data Availability}

The data used to support the findings of this study are available from the corresponding author upon request.

\section{Conflicts of Interest}

The authors declare that there are no conflicts of interest regarding the publication of this article.

\section{Acknowledgments}

This research was funded by the Major Technological Innovation Program of Hubei Province (Grant no. 2018AAA028) and the National Natural Science Foundation of China (NSFC) (Grant no. 51408203). The authors would like to express their appreciation to these financial assistances.

\section{Supplementary Materials}

S1 Table is corresponding to Figure 7. S2 Table is corresponding to Figure 9. S3 Table is corresponding to Figure 10. S4 Table is corresponding to Figure 11. S5 Table is corresponding to Figure 12. S6 Table is corresponding to Figure 13. S7 Table is corresponding to Figure 14. (Supplementary Materials)

\section{References}

[1] H. Chen, Y. Wu, H. Xia, B. Jing, and Q. Zhang, "Review of icepavement adhesion study and development of hydrophobic surface in pavement deicing," Journal of Traffic and Transportation Engineering (English Edition), vol. 5, no. 3, pp. 224-238, 2018.

[2] S. Liu and H. Zhao, "Research on snow removal technology in winter roads," Communications Science and Technology Heilongjiang, vol. 12, pp. 173-174, 2014.

[3] F. Yue, "Research situation and development of highway snow removing and ice melting technology," Northern Communications, vol. 5, pp. 62-65, 2014.

[4] C. Jiang, "Studies review of organization for winter road and maintenance program," Highway, vol. 4, pp. 215-219, 2012.

[5] H. Zhang, H. Wei, and J. Chen, "Review of research on rubber particle deicing snow asphalt pavement," Journal of China \& Foreign Highway, vol. 35, pp. 90-94, 2015.

[6] X. Zhang, Research on Anti-icing Technology of Rubber Particle Asphalt Pavement, Chang'an University, Xi'an, China, 2014.

[7] S. Luo and X. Yang, "Performance evaluation of high-elastic asphalt mixture containing deicing agent Mafilon," Construction and Building Materials, vol. 94, pp. 494-501, 2015.

[8] H. L. Dai, K. L. Zhang, X. L. Xu, and H. Y. Yu, "Evaluation on the effects of deicing chemicals on soil and water 
environment," Procedia Environmental Sciences, vol. 13, pp. 2122-2130, 2012.

[9] S. M. Green, R. Machin, and M. S. Cresser, "Effect of long-term changes in soil chemistry induced by road salt applications on N-transformations in roadside soils," Environmental Pollution, vol. 152, no. 1, pp. 20-31, 2008.

[10] M. Bäckström, S. Karlsson, L. Bäckman, L. Folkeson, and B. Lind, "Mobilisation of heavy metals by deicing salts in a roadside environment," Water Research, vol. 38, no. 3, pp. 720-732, 2004.

[11] B. D. Lee, Y. S. Choi, Y. G. Kim, I. S. Kim, and E. I. Yang, "A comparison study of performance and environmental impacts of chloride-based deicers and eco-label certified deicers in South Korea," Cold Regions Science and Technology, vol. 143, pp. 43-51, 2017.

[12] G. Blomqvist and E.-L. Johansson, "Airborne spreading and deposition of de-icing salt-a case study," Science of the Total Environment, vol. 235, no. 1-3, pp. 161-168, 1999.

[13] N. A. Lancaster, J. T. Bushey, C. R. Tobias, B. Song, and T. M. Vadas, "Impact of chloride on denitrification potential in roadside wetlands," Environmental Pollution, vol. 212, pp. 216-223, 2016.

[14] H. Yu, K. Zhang, and H. Dai, "Impact of chemical deicers on regional environment and the characteristics of its accumulation and translocation," Chinese Journal of Soil Science, vol. 42, pp. 1276-1280, 2011.

[15] B. Xiao, S. Wang, Y. Wang et al., "Effective thermal conductivity of porous media with roughened surfaces by FractalMonte Carlo simulations," Fractals, vol. 28, no. 2, Article ID 2050029, 2020.

[16] B. Xiao, W. Wang, X. Zhang et al., "A novel fractal solution for permeability and Kozeny-Carman constant of fibrous porous media made up of solid particles and porous fibers," Powder Technology, vol. 349, pp. 92-98, 2019.

[17] F. Ünal, G. Temir, and H. Köten, "Energy, exergy and exergoeconomic analysis of solar-assisted vertical ground source heat pump system for heating season," Journal of Mechanical Science and Technology, vol. 32, no. 8, pp. 39293942, 2018.

[18] T. Xie, J. Dong, H. Chen, Y. Jiang, and Y. Yao, "Experiment investigation on deicing characteristics and energy efficiency using infrared ray as heat source," Energy, vol. 116, pp. 998-1005, 2016.

[19] H. Xu, Y. Tan, and J. Spitler, "Study on the heat and mass coupled snow melting model for solar-ground source coupled heated pavement," Acta Energiae Solaris Sinica, vol. 35, pp. 804-810, 2014.

[20] J. W. Daniels and H. Ernest, "Development of anti-icing airfield pavement using surface-embedded heat wire," International Journal of Pavement Engineering, vol. 21, no. 6, pp. 725-735, 2020.

[21] D. Zhang, Z. Zhang, and J. Yuan, "Experimental research on deicing system by heating cables for highway bridges," Journal of Safety Science and Technology, vol. 11, pp. 90-95, 2015.

[22] J.-P. Won, C.-K. Kim, S.-J. Lee, J.-H. Lee, and R.-W. Kim, "Thermal characteristics of a conductive cement-based composite for a snow-melting heated pavement system," Composite Structures, vol. 118, pp. 106-111, 2014.

[23] J. Won, C. Kim, and S. Lee, "Improved mixture composition for early-opening heat-conductive concrete," Road Materials and Pavement Design, vol. 16, pp. 1-13, 2015.

[24] R. Hao, Built in Snow Melting Device Study on Design of Pervious Concrete Ground, Dalian University of Technology, Dalian, China, 2016.
[25] A. G. Mohammed, G. Ozgur, and E. Sevkat, "Electrical resistance heating for deicing and snow melting applications: experimental study," Cold Regions Science and Technology, vol. 160, pp. 128-138, 2019.

[26] H. Zhao, Z. Wu, S. Wang, J. Zheng, and G. Che, "Concrete pavement deicing with carbon fiber heating wires," Cold Regions Science and Technology, vol. 65, no. 3, pp. 413-420, 2011.

[27] Q. Zhang and Y. Zhao, "Deicing performance of carbon fiber heating wires embedded in concrete pavement," Journal of Highway and Transportation Research and Development, vol. 2, pp. 41-48, 2015.

[28] Y. Peng, M. Bao, and S. Chen, "Current situation and development of deicing technology with built-in carbon-fiber heating wires," Road Machinery \& Construction Mechanization, vol. 2, pp. 29-33, 2016.

[29] Z. Yang, T. Yang, G. Song et al., Experimental Study on an Electrical Deicing Technology Utilizing Carbon Fiber Tape, University of Alaska Anchorage, Anchorage, Alaska, 2011. 